\section{İzmir İktisat Dergisi İzmir Journal of Economics}

ISSN:1308-8173

E-ISSN: 1308-8505

Geliş Tarihi: 03.03.2020
Kabul Tarihi: 01.05.2020
YIL: 2020

Online Yayın: 29.06.2020

ÖZGÜN ARAŞTIRMA
Cilt: 35 Sayı: 2 Sayfa: $299-316$

Doi: $10.24988 /$ ije.202035207

\title{
Askeri Harcamaların İktisadi Büyümeye Etkisi: Sistem GMM Yaklaşımı ${ }^{1}$ Yücel ATÍLLA ${ }^{2}$, Recep KÖK ${ }^{3}$ \\ Özet
}

Çalışmanın temel amacı, askeri harcamaların; teknoloji veya pozitif dışsallıklar üzerinden büyümeyi uyarıcı etkisinin araştırılmasıdır. Uygulamalı literatürde yaygın bir şekilde işlenmiş olan bu çalışma, uzun dönemli iktisadi büyümenin asıl bileşenleri olan sermaye birikimi ve teknolojik gelişmenin; transfer niteliğindeki askeri harcamalar değişkeni ile ne ölçüde ve nasıl etkileșim içinde olduğu konusunu incelemektedir. Burada, 33 OECD ülkesinin gözlem değerlerinden hareketle Genișletilmiș Solow Modeli ve Feder-RAM temelli modeller üzerinden; Sistem GMM yöntemiyle tahmin edilmiș model katsayıları yorumlanmıştır. Çalışmanın bulguları açısından, askeri harcamalar değişkeninin büyümeye etkisi Genişletilmiş Solow Modelinde negatif, aynı değișkenin gecikmeli değeri nise pozitif etkiye shiptir. Gecikmeli değerin pozitif etkisi akla teknolojik gelişmenin işlevsel yaylma etkisini getirmektetir. Feder-RAM temelli modelin tahmini sonucunda, askeri harcamalar değişkeninin büyümeye pozitif katkı yaptığı gözlemlenmiş olmakla birlikte çıktı içindeki payının değişim oranının negatif etki göstermesi, sivil sektör kaynaklı büyümenin baskın olması gerektiği hususunu düşündürmektedir. Bununla birlikte, her iki model de askeri harcamaların büyümeye etkisi kısmen önemlidir. Çünkü modelin tahmincisi katsayılar oldukça küçüktür. Ancak, devletlerin bekası gereği yapılması zorunlu olan bir harcama olan askeri mal ve hizmet üretiminin büyümeye katkısının artırılması için teknoloji ve bilgi artışını sağlayan sabit sermaye yatırımları ve arge harcamalarının verimliğini artıracak politikalar geliştirimesi önemli olup karar alıcılar aaçısından da önensenmelidir. Bu çalışmada, hafif silah üreten firmaların sivil talep yönlü desteklenmesinin teknoloji dışşalığını artıracağı beklentisi ek bir öneri kapsamında sunulmaktadır.

Anahtar kelimeler: Askeri Harcamalar, Genișletilmiș Solow Modeli, Feder-Ram Modeli, Sistem GMM Yaklașımı. Jel Kodu: C23, H56, 040

\section{The Effect of Military Expenditures on Economic Growth: System GMM Aproach}

\section{Abstract}

The main purpose of this study is to investigate the effect of military expenditures on economic growth via technology or positive externalities. This study examines the extent and interaction level of military expenditures with the main components of long-term economic growth, capital accumulation and technological progress. We run a panel data of 33 OECD countries and used System GMM to estimate the Augmented Solow and Feder Ram models. The study finds that the effect of the military expenditures on growth is negative and its lagged value is positive. The positive effect of the lagged value of the military expenditure brings to mind the functional spillover effect of technological advance. The estimation of Feder-RAM based model reveals that military expenditure has positive contribution to growth, although negative sign of the changing in military expediture GDP share suggests that civil sector driven growth should be dominant in economy. However, both models conclude that the impact of military spending on growth is small, but not insignificant. We conclude that the share of the millitary fixed capital investment and military R\&D expenditures must be higher in order to increase the contribution of military expenditure to growth. Our study also proposes that supporting small arms producing sector via civil demand may also increase the positive effect of technology.

Keywords: Military Expenditures, Augmented Solow Model, Feder-Ram Model, System GMM Approach. Jel Codes: C23, H56, 040

\section{GÍRİS}

Üretim ve ekonomik büyümenin temel unsurlarının emek, sermaye birikimi, teknoloji ve beșeri sermaye odaklı olduğu bilinmektedir.
Bununla birlikte, büyümenin ana dinamiği niteliğindeki iki olgudan biri olan sermaye birikimi, uzun dönemli ekonomik büyüme için gerekli ancak yeterli koşul sayılmaz iken; uzun dönemli ekonomik büyümenin itici gücünün

\footnotetext{
${ }^{1} \mathrm{Bu}$ çalışma doktora tezinden türetilmiştir (Atilla, 2019).

ATIF ÖNERISI (APA): Atilla, Y., Kök, R., (2020). Askeri Harcamaların İktisadi Büyümeye Etkisi: Sistem GMM Yaklaşımı. İzmir Iktisat Dergisi. 35(2). 299-316. Doi: 10.24988/ije.202035207

2 Dr., Dokuz Eylül Üniversitesi, Sosyal Bilimler Enstitüsü, Buca / İZMİR; T.C. Ziraat Bankası Yönetmeni, y.atilla@gmail.com ORCID: 0000-0002-4512-7828

3 Öğr. Üyesi Prof.Dr., Dokuz Eylül Üniversitesi, İktisadi ve İdari Bilimler Fakültesi, Buca / İZMİR, recep.kok@deu.edu.tr ORCID: 0000-0002-2048-0182
} 


\section{Y. ATILLA - R. KÖK}

teknoloji olduğu bilinmektedir. Teknolojik ilerleme, sermayenin verimliğini/etkinliğini arttırırken; etkin nüfus büyümesinin kaynaklar üzerinde ortaya koyduğu olumsuz etkiyi telafi eden yegâne faktör olarak sürekli büyümenin ana kaynağıdır.

İlgili literatürden bilinen çalışmalar, askeri harcamaların iktisadi büyüme ve ulusal refahı olumlu etkilediği gibi "dışlama etkisi" (crowding-out) yoluyla olumsuz etki de gösterebildiğini ortaya koymuştur. Nitekim etkileşim süreci, niteliksel yaratıcılık etkisi ile kaynakların etkin kullanımına olanak verebilirken, potansiyel olarak daha üretken alanlarda kullanılması gereken kaynakların daha verimsiz alanlara aktarılması sonucunda iktisadi büyümenin beklenen düzeyin altında kalmasina da neden olabilmektedir. $\mathrm{Bu}$ yönüyle, çalışmanın temel hipotezi tarafımızca şu şekilde kurulmuştur: "Askeri harcamalar, ekonomik büyüme üzerinde diğer kamusal harcamalara göre daha uyarıcı bir katkı sağlar."

Burada askeri harcamalar, sermaye birikimi üzerine etki eden dişsal değişken olarak kabul edilmekte ve tarafımızca yukarıda kurulan temel hipotez çalışmanın sınırları içinde test edilmektedir. $\mathrm{Bu}$ çalışma, literatürden bildiğimiz kadarıyla crowding in ve crowding out içerikli bir hipotez oluşturması ile bir ilk olma özelliğini taşımakta ve diğer çalışmalara göre farkını özgün kılmaktadır. Çalışma üç bölümden oluşmaktadır. İlk kısımda, iktisadi büyüme teorilerinin kuramsal çerçevesi özet bir yaklaşımla ele alınmaktadır. Ayrıca askeri harcamalar üzerine betimsel göstergelere kısaca yer verilmektedir. İkinci kısım ise askeri harcamalar ve büyüme ilişkisi üzerine bir uygulamadan oluşmaktadır. Üçüncü ve son kısımda sonuç ve politika önermeleri yer almaktadır.

\section{ASKERİ HARCAMALAR VE BÜYÜME ÜZERINNE TEORİK ÇERÇEVE: LİTERATÜR VE MODEL}

Askeri harcamaların ekonomik etkileri üzerine yazılmış literatür değerlendirildiğinde Smith R. P., 2000; Dunne J. P., 1996; Smith A. , 1776; Benoit, 1978; Bleaney ve Nishiyama, 2002;
Yeşilyurt ve Elhorst, 2017; Keller, Poutvaara, ve Wagener, 2009; özellikle ana-akım büyüme literatürü incelendiğinde askeri harcamaların büyüme üzerinde etkili bir faktör olduğu konusunda net bir kanıt bulunamamıştır. $\mathrm{Bu}$ konudaki en önemli çalışmalardan birini yapmış olan Sala-i Martin, seksen sekiz ülkeyi kapsayan; 1960-1996 yıllarındaki büyümenin temel açıklayıcılarını ele aldığı çalışmasında altmış yedi değişken arasında askeri harcamaların yarattığı etkiyi de araştırmasında göstermiştir (Sala-i-Martin, Doppelhofer, ve Miller, 2004). Kendi çalışmamız açısından, teorik arka-plan özet olarak aşağıda ele alınmış ve modele ilişkin kısa bir açıklama da yapılmıştır.

Geliştirilmiş Solow Modeli, Mankiw vd. tarafından geliştirilmiştir (Mankiw, Romer, ve Weil, 1992). Bu yaklaşım da ilk defa Knight vd. (1996) tarafından yapılan çalışma ile askeri harcamaların büyüme üzerindeki etkilerini ölçmek için kullanılmıştır. Bu çalışmadaki anahtar varsayım, askeri harcamaların çıktıdaki payı; $m=M / Y$ değişkeninin, iktisadi büyümeyi işgücünü geliştirici teknik ilerleme vasıtasıyla etkilemesidir. Model Cobb-Douglas türü neo-klasik toplam üretim fonksiyonundan türetilmektedir: Buna göre fonksiyonel form şu șekildedir:

$Y(t)=K(t)^{\alpha}[A(t) L(t)]^{1-\alpha}$

Burada Y: Toplam reel çıktı, K: $\alpha$ reel sermaye stoku ve kısmi verimliliği, L: işgücü miktarı ve $1-\alpha$ : iş gücünün kısmi verimliğidir. Teknolojik gelişim katsayısını ifade eden A parametresi ise askeri harcamaların dışsallıklarını içerecek şekilde aşağıdaki gibi formülize edilmektedir:

$A(t)=A_{0} e^{g t} m(t)^{\theta}$

$e^{g t}$ : Dişsal Harrod-neutral teknik gelişme katsayısını, mt: askeri harcamaların reel gayri safi yurtiçi hasıla (GSYIH) içindeki payıdır. Buna göre, m'deki kalıcı bir değişme, uzun dönem durağan durum büyüme oranını etkilemez ancak kişi başına düşen gelir düzeyinde; durağan duruma yakınsama süreci boyunca geçici bir seviye artışına neden olabilir veya yeni bir durağan durum denkliğine geçiş 
sürecindeki büyüme oranlarını kalıcı olarak etkileyebilir.

Standart Solow Modeli varsayımlarıyla birlikte dışsal tasarruf oranı olarak s, sabit işgücü artıșı parametresi olarak $\mathrm{n}$ ve sermayenin aşınma oranı $\delta$ olarak alınarak; sermaye birikim dinamiği aşağıdaki gibi formülize edilebilir:

$\dot{k}_{e}=s k_{e}^{\alpha}-(g+n+\delta) k_{e} \Leftrightarrow \frac{\partial l n k_{e}}{\partial t}=s e^{(\alpha-1) l n k_{e}}-(g+n+\delta)$

Burada, $k_{e}=K /[A . L]$ etkin sermaye - emek oranını ve $\alpha$, sabit sermayenin çıktı esnekliğini temsil etmektedir. $k_{e}$ değişkeninin durağan durum seviyesi de aşağıdaki gibi yazılabilir:

$\mathrm{k}_{\mathrm{e}}^{*}=\left[\frac{\mathrm{s}}{\mathrm{g}+\mathrm{n}+\delta}\right]^{1 /(1-\alpha)}$

Denklem (4)'ü durağan durum seviyesi noktasında sınırlanmış Taylor Serisi açılımı yoluyla doğrusallaştırdığımızda:

$\frac{\partial \ln k_{e}}{\partial t}=(\alpha-1)(g+n+\delta)\left[\ln k_{e}-\ln k_{e}^{*},\right]$

$\ln y_{e}=\ln [Y /(A . L)]$ olduğu için,

$\frac{\partial \ln y_{e}}{\partial t}=(\alpha-1)(g+n+\delta)\left[\ln y_{e}-\ln y_{e}^{*}\right]$

Etkin işgücü başına durağan durum çıktı düzeyi denklemi de aşağıdaki gibi yazılabilir:

$y_{e}^{*}=\left[\frac{s}{g+n+\delta}\right]^{\alpha /(1-\alpha)}$

Ayrıca daha önce yazılmış olan (5) numaralı denklem, durağan durum noktasına yakın geçici etkin işgücü başına çıktı seviyesine yakınsar.

Çalışmamız için çok önemli olan bir nokta olarak, (5) numaralı denklemi ekonometrik kullanıma uygun hale getirilebilmek için, $\mathrm{t}-1$ den t zamanını içeren değişkenler eklenmiştir:

$\operatorname{lny}_{e}(t)=e^{z} \ln y_{e}(t-1)+\left(1-e^{z}\right) \ln y_{e}^{*}, z \equiv(\alpha-1)(n+g+\delta)$

(1), (5) ve (7) numaralı eșitlikler kullanılarak, $y_{e}$ gözlemlenebilir kişi başı çıtı $y=Y / L$ ile ilişkilendirilir:

$\ln y(t)=e^{z} \ln y_{e}(t-1)+\left(1-e^{z}\right)\left\{\ln A_{0}+\frac{\alpha}{1-\alpha}[\ln s-\ln (n+\right.$

$g+d)]\}+\theta \operatorname{lnm}(t)-e^{z} \theta \operatorname{lnm}(t-1)+\left(t-(t-1) e^{z}\right) g$.

Önemli bir not olarak şu ifade edilmelidir ki, en nihai anlamda durağan durum kişi başına gelir denkliği aşağıdaki gibi olacaktır: $\ln y^{*}(t)=\ln y_{e}^{*}+\ln A_{0}+\theta \ln m^{*}+g t$

Denklem (10)'un yukarıda yazılmış tanımlamasına göre, $\theta$ uzun dönem askeri harcamalar oranının, durağan durum gelir esnekliğini temsil eder. Yani, uzun dönem askeri harcamalarda gerçekleşecek \%1'lik bir değișim, uzun dönem durağan durum kişi başına gelir eğrisini $\% \theta$ olarak kaydırır şeklinde yorumlanmıştır.

Eşitlik genellikle, bir başlangıç (ex-ante) ve bir bitiş yılı (ex-post) verisi kullanılan yatay-kesit verilere göre tahmin edilecektir ve tahmin denklemimiz aşağıdaki gibi ifade edildiğinde;

$\Delta \ln y(t)=\beta_{0}+\beta_{1} \ln y(-1)+\beta_{2} \ln s+\beta_{3} \ln (n+g+\delta)+$ $\beta_{4} \operatorname{lnm}(t)+\beta_{5} \ln m(-1)+\epsilon$

$\mathrm{Bu}$ sistematikte aynı Feder-Ram modelinde olduğu gibi bağımlı değişken büyüme oranıdır. Büyüme oranı da yatırımların (tasarruflara denkliği unutulmamalıdır) ve iş gücünün büyüme hızlarının artan bir fonksiyonudur. Askeri harcamalar değişkeni olarak t zamanlı ve bu değişkenin gecikmeli oransal değeri olarak alınmıştır. Askeri harcamalar çıktıyı adhoc șeklinde etkilediği düșünülmüș olmakla birlikte askeri harcamaların teknolojiyi nasıl değiștirdiği konusu matematiksel anlamda net değildir. Askeri harcamalar seviyesindeki değişmelerin, tasarruf oranlarını ile bütçe kısıtını nasıl etkileneceğine dair açık bir tanımlama da yoktur. Aynı zamanda modelin eleştiri alan yönlerinden bir tanesi de hata terimlerinin türetilmesinde kullanılan yöntemdir. Modelde hata terimi, ad hoc tarzda verildiği üzere stokastik teknoloji ve iş gücü büyümesi üzerinden türetilmiştir (Lee, Pesaran, ve Smith, 1997). Teori, tahmin edilmiş katsayıların sınanması kisıtlamalarıyla ve neyin değişken neyin parametre olduğuna ilişkin açık ayrımlarıyla daha sağlam temellere dayanmakla birlikte, $(n+g+\delta)$ teriminin z'nin içinde bir parametre ve değişken olarak yer alması bu açıklığa olumsuz bir etkide bulunmuștur. Buna ek olarak modelde yer alan önemli bir varsayım olarak sermaye oranının tüm örnek ülkeler açısından sabit kabul edilmesi bir sorun kaynağı olarak kabul edilebilir. Prensipte, Genişletilmiş Solow 


\section{Y. ATILLA - R. KÖK}

Modeli iyi kurgulanmış olmasına rağmen modele yapılan eklentilerin ortaya koyduğu sorunlar açıkça incelenebilir.

Ayrıca büyüme üzerine yapılan nispeten daha yeni görgül (ampirik) çalışmalar, büyümeyle sağlıklı bir şekilde ilgileşimli değişkenler içeren ad hoc modelleri aramaktadır. Bu sağlam ilgileşimin nasıl sağlanacağı ise hala tartışılan bir konudur. Sala-i-Martin vd. (Sala-i-Martin, Doppelhofer, ve Miller, 2004) ile Bleaney ve Nishiyama bu konu ile alakalı farklı yaklaşımlar olarak sayılabilir (Bleaney ve Nishiyama, 2002). Bu açıklamalar ışığında Genişletilmiş Solow Modeli kullanılarak yapılan uygulamalı çalışmalar aşağıda Tablo 1 de listelenmiştir.

Tablo 1: Genişletilmiş Solow Modelini Kapsayan Çalıșmalar

\begin{tabular}{|c|c|c|c|c|}
\hline ARAŞTIRMACI & $\begin{array}{l}\text { VERİ } \\
\text { BíçíMİ }\end{array}$ & $\begin{array}{l}\text { VERİ SETİ } \\
\text { ZAMAN } \\
\text { ARALIĞI } \\
\end{array}$ & TAHMİN YÖNTEMİ & $\begin{array}{c}\text { ASKERİ HARCAMA PROXY } \\
\text { DEĞİŞKENI-Açılayıcı } \\
\text { Değişken }\end{array}$ \\
\hline $\begin{array}{c}\text { Knight, Loayza, ve Villanueva, } \\
1996\end{array}$ & $\mathrm{P}^{*}$ & $1972-1990$ & Panel OLS & M/GDP \\
\hline Smith ve Dunne, 2001 & $\mathrm{P}$ & $1960-1997$ & Pooled OLS, VAR, RCM & M/GDP \\
\hline Dunne, Nikolaidau ve Smith, 2002 & $\mathrm{P}$ & 1960-1997 & Pooled OLS FE, RCM, VAR & $\mathrm{M} / \mathrm{GDP}$ \\
\hline Heo, 2009 & $\mathrm{TS}^{* *}$ & $1954-2005$ & OLS & M/GDP \\
\hline $\begin{array}{l}\text { Keller, Poutvaara, ve Wagener, } \\
2009\end{array}$ & CS & $1960-2000$ & Pooled OLS & M/GDP \\
\hline Yılıdırım ve Öcal, 2014 & $\mathrm{P}$ & $2000-2010$ & Spatial Data Analysis & M/GDP \\
\hline Dunne ve Nikoladiau, 2012 & $\mathrm{P}$ & $1961-2007$ & OLS & $\mathrm{M} / \mathrm{GDP}$ \\
\hline Dunne, 2012 & $\mathrm{P}$ & 1988-2006 & Fixed Efect OLS & M/GDP \\
\hline Hou ve Chen, 2012 & $\mathrm{P}, \mathrm{CS}^{* * *}$ & $\begin{array}{l}1970 / 5- \\
2009\end{array}$ & System GMM & M/GDP \\
\hline
\end{tabular}

Burada, $\mathrm{P}^{*}$ : Panel Veri, $\mathrm{TS}^{* *}$ : Zaman Serisi, $\mathrm{CS}^{* * *}$ : Yatay kesiti gösterir.

Genişletilmiş Solow Modelinin uygulamalı çalışmaları arasında yer alan Knight vd. 'nin 79 ülkenin 1973-1990 yılları arasındaki verileriyle yaptıkları çalışma (Knight, Loayza, ve Villanueva, 1996) ile Smith vd. 2001'de 28 ülkeyi ve 1960-1997 arası dönemi kapsayan çalışma (Smith ve Dunne, 2001) doğrudan çalışmamızla ilişkili olmamakla birlikte uygulamalı literatür benzerliği nedeniyle incelenmiştir. Burada bulguları ve kullandığı yöntem bağlamıyla çalışmamızla kesişen Hou vd.'nin yaptığı çalışma ele alınmaktadır (Hou ve Chen, 2012). Araştırmacılar, 35 gelişmekte olan ülkenin 1975-2009 dönemleri arasında yer alan verileri kullanmakta ve araştırmamızla uyumlu katsayılar elde etmektedirler. Karşılaştırmanın sonuçları analiz bütünlüğü içinde tekrar ele alınacaktır.

$\mathrm{Bu}$ çalışmamıza referans alınan ve uygulamamıza konu olan diğer bir model ise Feder-Ram modelidir $(1983,1986)$. Adı geçen çalışmanın tamamlanmasından sonra "gunsand-butter" tartışmasına birçok katkı aynı yaklaşımın farklı tarzlarıyla uygulanmıştır. Yine Deger ve Sen tarafindan Feder-BiswasRam dişsallık modeli "askeri harcamaların büyüme üzerine etkisini araştırmak için mükemmel bir koşum atı" olarak değerlendirilmiș (Deger ve Sen, 1995); Ram modelinin açıklanmasına geçmeden önce (Yıldırım, Sezgin, ve Öcal, 2005), (Heo ve Hahm, 2006), (Heo ve DeRouen Jr., 1998) çalışmalarına da atıf yapmakta yarar görülmüștür. $\mathrm{Bu}$ yaklaşım genellikle "neoklasik büyüme teorisinden esinlenerek Mintz ve Stevenson (1995) tarafından ele alınmış ve Biswas ve Ram (1986) tarafından da askeri harcamalar değişkeni tek denklemli büyüme regresyona dâhil edilmiștir. Modelin basit iki sektörlü türü, askeri çıktı (M) ve sivil çıktı (C) arasındaki ilgileşime dayanır. İki sektör de homojen işgücü (L) ve sermaye (K) kullanmakla birlikte askeri üretimin, sivil 
üretime etki eden dişsallıklara sahip olduğu varsayılmakta ve tanımları denklem (12)'de verilmektedir.

$M=M\left(L_{m} K_{m}\right), \mathrm{C}=\left(L_{c}, K_{c}, \mathrm{M}\right)=M^{\theta}\left(L_{c}, K_{c}\right)$

Faktör donatım kısıtları aşağıdaki gibi ifade edilebilir:

$L=\sum_{i \in S} L_{i}, K=\sum_{i \in S} K_{i}, \quad S=\{m, c\}$

Milli geliri ifade etmesi açısından:

$Y=C+M$

Doğal olarak denklemdeki "üretim", "tüketimin" ve "savunma giderlerinin" niceliksel büyüklüklerinin toplamı olarak değil de parasal büyüklükleri olarak kabul edilirse kullanılabilir duruma gelebilir. Bu açıklamalar doğrultusunda denklemi yeniden yazarak, denklemde ima edilen fiyat normalleşmesini açıkça belirtmek faydalı olabilecektir. Denklem (14)'e denk olarak milli gelir (toplam çıtı) denkliğini aşağıdaki gibi de yazılabilir:

$Y=P_{c} \operatorname{Cr}\left(L_{c}, K_{c}, M\right)+P_{m} \operatorname{Mr}\left(L_{m}, K_{m}\right)$

$\mathrm{P}_{\mathrm{m}}$ ve $\mathrm{P}_{c}, \mathrm{M}_{\mathrm{r}}$ ve $\mathrm{Cr}_{\mathrm{r}}$ nin reel çıktı miktarıyla ilintili fiyat değerlerini gösterir. Model işgücü $\left(\mathrm{M}_{\mathrm{L}}\right.$, $\left.\mathrm{C}_{\mathrm{L}}\right)^{\prime}$ nin ve kapital $\left(\mathrm{M}_{\mathrm{K}}, \mathrm{C}_{\mathrm{K}}\right)^{\prime}$ nin marjinal ürünlerinin değerleri sektörler arasında sabit bir oranda farkllllk göstermesine izin verir.

$\frac{M_{L}}{C_{L}}=\frac{M_{K}}{C_{K}}=1+\mu$

ya da (15) numaralı denkleme denk olarak:

$\frac{P_{m} M r_{L}}{P_{c} C r_{L}}=\frac{P_{m} M r_{k}}{P_{c} C r_{k}}=1+\mu$

(17) numaralı denklem, farklı sektörler arasındaki marjinal faktör verimliliklerinin karşılaştırılmalarının; sektörel çıtılırın değerlendirilmesinde kullanılan fiyatlara bağlı olarak yapıldığını gösterir. Denklem (14)'ün denklem (12) ve denklem (13) ile orantılı fark denklemi, büyüme denklemini verir:

$\widehat{Y}=\frac{C_{L} L}{Y} \widehat{L}+C_{K} \frac{I}{L}+\left(\frac{\mu}{1+\mu}+C_{M}\right) \frac{M}{Y} \widehat{M}$

" $\wedge$ " işareti orantılı değişim oranlarını ve $I=$ $d K$ net yatırımı gösterir. Gerçek kullanımı itibarlyla birinci denklemin son terimi C'nin M'ye göre esnekliğinin sabit olmasına yol açmaktadır. Bu bağlamda, (18) numaralı denklem aşağıdaki şekilde yeniden yazılabilir:

$\widehat{Y}=\frac{C_{L} L}{Y} \widehat{L}+C_{K} \frac{I}{Y}+\left(\frac{\mu}{1+\mu}-\theta\right) \frac{M}{Y} \widehat{M}+\theta \widehat{M}$

Denklem (18) ve (19)'un türevleri, ülke-kesit veri (Biswas ve Ram, 1986), ülke özelinde zaman serileri verileri [ (Huang ve Mintz, 1990); (Ward, Davis, ve Chan, 1993); (Sezgin, 1997); (Antonakis, 1999); (Batchelor, Dunne, ve Saal, 2000)] ve panel veriler kullanılarak tahmin edilmiştir (Murdoch, Pi, ve Sandler, 1997).

Denklem (17)'de yer alan sektörler arası marjinal faktör verimlilikleri farklılı̆̆ birkaç yorumsal tuzağa kaynaklık etmektedir. Ampirik çalışmalarda sıfırdan farklı tahmin edilen " $\mu$ " nün; bir sektörün diğerinden "daha az verimli" ya da "daha az etkin" faktör kullanımının, bir çeșit organizasyonel başıbozukluğun veya " $\mathrm{X}$ " değiş̧keninin etkinlikten uzak olması sonucunda sektörü sarsmasının bir yansıması olarak yorumlanmıştır. Örneğin, (Ward, Davis, ve Chan, 1993) çalıșmalarında, sivil sektöre kıyasla askeri sektörün daha az verimli olması sebebiyle Tayvan için negatif bir $\mu$ hesaplanmıştır. Benzer bir çalışmayı Türkiye için gerçekleştiren (Sezgin, 1997) de benzer bir şekilde negatif bir $\mu$ değerine ulaşmış ve bunu "Savunma sektörünün daha az piyasa disiplinine sahip olması sebebiyle sivil sektörün, askeri sektörden daha üretken olması" ş̧eklinde yorumlamıștır. Benzer şekilde, (Antonakis, 1997), (Ateşoğlu ve Mueller, 1990)'in çalışmasını tekrar ederek: Sektörü uyarıcı, güçlü bir rekabet baskısından yoksun savunma sanayi firmalarında diğer sektör firmalarına göre etkinliğin düşük olması sonucuna ulaşmışlardır. Dolayısıyla savunma sanayi sektöründe yer alan firmaların marjinal faktör verimliliklerinin daha düşük olduğu hususu tartışılabilir ifadesini not düşmüşlerdir.

Bu tarz açıklamalar ile düşülen yorumsal tuzak neticesinde, altta yatan teorik modelle çelişir hale gelinmektedir. Bu nokta, literatürde fark edilmemiş gibi duruyor olsa da üretimdeki teknik etkinlik modelde bir varsayım olarak 


\section{Y. ATILLA - R. KÖK}

kaimdir. Denklem (19)'da her iki faktör için faktör verimlilikleri farklılığının istikrarını tatbik ederek, iki sektörlü Feder-Ram modeline dayanan çalışma, her iki sektörün üretiminin, üretim olanakları eğrisinin üzerinde yer alan etkinlik sınırında gerçekleştiğini göstermektedir. Üretimdeki teknik verimlilik, C (sivil) üretimi; M (askeri sektör)'den fedakârlık yapmadan artırılamıyorsa veya tam tersi geçerliyse, maksimumdur. $\mathrm{Bu}$ üretim sektörlerindeki işgücü ve sermayenin arasındaki marjinal teknik ikame oranlarının birbirlerine eşitlenmesini gerektirir.

$M R T S_{M}=M r_{k} / M r_{L} \quad$ ve $\quad M R T S_{C}=C r_{k} / C r_{L}$ olduğuna göre, etkinlik şartı $M r_{k} / M r_{L}=$ $C r_{k} / C r_{L}$ şeklinde yeniden düzenlenebilir ve bu varsayım Denklem (17)'ye denktir.

Sıfırdan farklı bir $\mu$ 'nün, kaynakların kullanımında sektör-spesifik verimsizliği ölçtügüne dair öneri kusurlu gibi görünmektedir. Reel GSYIH'nin hesaplanmasında kullanılan örtük fiyat oranı $P=P_{m} / P_{c} ; \quad C_{r}$ ve $M_{r}$ arasındaki değişimin (bu değişim halkın "savunma" için vazgeçmesi gereken "üretim" miktarını ölçer) marjinal oranından saptığında sıfırdan farklı bir $\mu$ oluşturmaktadır. $P<M R T, \mu<0$ olduğunda ve denklem (12)'ye göre hesaplanmış toplam reel çıktı, kaynaklar savunmadan sivil üretim sektörlerine aktarılırsa yükselir.

Buna mukabil, eğer $P>M R T$ ve $\mu>0$ ise tam tersi (vice versa) gerçekleşerek düşüş yaşar. Ancak faktörlerin yeniden tahsis edilmesi ile sağlanan toplam reel çıktı büyümesi, yoğun rekabet ortamının eksikliğinden kaynaklanan verimsizlik sonucu kaynakların daha iyi yönetilen bir sektöre kaydırılması şeklinde ortaya çıkmamaktadır. Başka bir deyişle, reel çıktı; kaynakların M'den C'ye kaydırılması sonucu yükselmiştir.

Aynı zamanda bir diğer potansiyel karşı sav olarak, üretim olanak alanının dışında hareket gösteren bir fonksiyon yakalamaya çalışan bu yaklaşımın geçersizliği öne sürülebilir. Ampirik büyüme denkleminin türetilmesinde kullanılan üretim fonksiyonu, aynı zamanda verimsizliği ya da sektör içi verimsizlikleri tanımlamak üzerine geliştirilmemekle birlikte yapısı gereği sektörler arası organizasyonel verimsizlikleri hesaplama becerisine de sahip değildir.

Daha derinlemesine sorgulanacak olursa, çıktının hesaplanmasında kullanılan göreli fiyatların (P) değeri bilinmeden, marjinal teknik ikame oranı hesaplanabilir mi? Yani, bu belirsizlikler altında karar alıcılar iktisadi kaynakları sivil üretim sektöründen, askeri üretim sektörüne kaydırmakta istekli olacak mıdır? Eğer iktisadi karar alıcılar böylesine bir kaynak transferine icazet verecekse, sifirdan farklı bir $\mu$, ekonominin tamamında ortaya çıkan verimsizlik ve sektörler arası faktör tahsisi konusunda ortada olan etkinlik dıșı durumdan bağımsız olduğunu düşündürmektedir. Tüm sektörlerdeki girdilerin çıktıya dönüştürmek için harcanan gayret ya da beceriden de bağımsız olduğu düşünülebilir.

$\mathrm{Bu}$ teorik problemlere ek olarak, Feder-Ram modelinin tahmininde birkaç ekonometrik problemin de varlığı tartışılmalıdır. Denklem (15)'in türetilmesinde neyin değişken neyin katsayı olduğunu açıklayan hiçbir ayrıt yoktur. Pratikte stokastik tahmin denklemi, denklem (18)'e hata terimi eklenerek elde edilmiştir.

Modelde sermaye (yatırım değişkenine oransal olarak katılarak) ve işgücü (büyüme değişkenine oransal olarak katılarak) asimetrik bir şekilde modele etki eder. $C_{K} \frac{I}{Y}$ terimi bir değișkene ve bir katsayıya ayrılırken; $\beta_{2} \frac{I}{Y}$ ve $\frac{C_{L} L}{Y}$ teriminin sabit bir $\beta_{1}$ olarak kabul edilip edilemeyeceği açık değildir. Hata terimlerinin kaynağı olarak hangi etkilerin neden olabileceği açık olmamakla birlikte hata terimlerinin beyaz gürültüye uygun bir istatistiki dizilime sahip olup olmadığ bilinmemektedir. Modelde gelişen teknoloji sürecini temsil eden değișken olarak sadece askeri dışsallıklar içerilirken diğer teknoloji geliştirici süreçler modelde dışlanmıştır ancak bu problem denklem (19)'a bir sabit terim ekleyerek ad hoc tarzında çözülebilir. Askeri harcamaların artış hızını denklemin sağ tarafında olması ciddi eşanlılık (aşırı 
belirlenme) problemlerine yol açmaktadır. Eğer askeri harcamaların oranı sabit ise çıktıdaki artış değişimleri askeri harcamaların artışını belirler. Son iki terimdeki çoklu ardışık bağımlılık, büyük standart hatalara ve dışsallık katsayının yanlış tahmin edilmesine sebep olabilir. Model, hiç gecikmeli parametre veya bağlı değişkenin olmadığı durağan bir biçimsel yapıya sahiptir. Bununla birlikte zaman serilerinin doğasında yer alan yavaş uyarlanmanın (intibak) varlığ ve bu anlatılanın sonucu olarak toplam çlktının gecikmeli değerinin de büyümenin önemli bir belirleyicisi durumunda olması dolayısıyla değişkenlerin gecikmeli değerlerinin modele dâhil edilmemesi, Feder-Ram metodolojisini sorunlu kılmaktadır (Dunne, Smith, ve Willenbocker, 2005). Tüm bu sorunlarına rağmen, Feder-Ram modelinin yukarıda bahsedilen kısıtlamalarından kurtarmak için yapılan bazı ad-hoc eklemeler [Örneğin, (Crespo Cuaresma ve Reitschuler, 2004)'in askeri harcamaların lineer olmayan etkilerini hesaba katan bir eklemesi] olsa da modeli kullanmamak için güçlü teorik ve ekonometrik nedenler önem arz etmektedir. 1980'lerde Feder yaklaşımı, deneysel ihracat-büyüme ve devlet harcamaları-büyüme yazılarında çok kullanılmaktayken günümüzde savunma ekonomisi yazıları haricinde pek kullanılmamaktadır. Feder-Ram modeli ve türevlerine ilişkin yukarıda yapılan teorik tanıtım ve eleştirel bakış açısıyla birlikte, bu modelin kullanılarak yapılan uygulamaların araştırmacılara sergilediği bulgular özetlenmiştir. Şimdi ise, Feder-Ram Modeli ve uygulamalarına ilişkin literatürün önemli bir bölümü aşağıdaki Tablo 2'de verilmiştir.

Tablo 2: Feder-Ram Modeli Uygulamalı Literatür Tablosu

\begin{tabular}{|c|c|c|c|c|}
\hline ARAŞTIRMACI & $\begin{array}{c}\text { VERì } \\
\text { BíçiMí }\end{array}$ & $\begin{array}{c}\text { VERI SETI ZAMAN } \\
\text { ARALIĞI } \\
\end{array}$ & TAHMIN YÖNTEMI & $\begin{array}{c}\text { ASKERİ HARCAMA PROXY } \\
\text { DEĞișKENİ-Açıklayıcı Değişken }\end{array}$ \\
\hline Alexander W. R., 1990 & $\mathrm{P}$ & 1974-1985 & Pooled OLS & M/GDP \\
\hline Ateşoğlu ve Mueller, 1990 & TS & 1990-1995 & Yinelemeli OLS & M/GDP \\
\hline Huang ve Mintz, 1990 & TS & 1949-1989 & OLS ve ORR & M/GDP \\
\hline Mintz ve Huang, 1990 & TS & $1987-1990$ & $\begin{array}{l}\text { SUR: Seemingly Unrelated } \\
\text { Regression }\end{array}$ & M/GDP \\
\hline Stewart, 1991 & $P$ & $1952-1969$ & OLS & M/GDP \\
\hline Biswas B. , 1992 & CS & 1989-1992 & OLS & M/GDP \\
\hline Linden, 1992 & $\mathrm{P}$ & $1973-1985$ & GLS: Generalized Least Squares & $\mathrm{M} / \mathrm{GDP}$ \\
\hline Alexander W. R., 1995 & $\mathrm{P}$ & 1966-1988 & Pooled OLS & M/GDP \\
\hline Heo, 1996 & TS & 1954-1988 & OLS & M/GDP \\
\hline Heo ve Kwang , 1998 & TS & $1954-1980$ & OLS & M/GDP \\
\hline Heo ve DeRouen Jr., 1998 & TS & $1961-1990$ & NLS: Non-Linear Least Squares & $\mathrm{M} / \mathrm{GDP}$ \\
\hline Heo, 2000 & TS & 1948-1996 & OLS & M/GDP \\
\hline Sezgin, 2000 & TS & 1957-1994 & OLS & M/GDP \\
\hline Stroub ve Hackelman, 2001 & $P$ & $1975-1989$ & OLS & M/GDP \\
\hline Klein, 2004 & TS & 1970-1996 & 3S-OLS & $\mathrm{M} / \mathrm{GDP}$ \\
\hline Reitschuler ve Loening, 2005 & TS & 1951-2001 & OLS & M/GDP \\
\hline Yıldırım, Sezgin, ve Öcal, 2005 & $\mathrm{P}$ & 1987-1997 & System GMM & M/GDP \\
\hline Heo ve Hahm, 2006 & TS & $1968-2001$ & 3S -OLS & M/GDP \\
\hline
\end{tabular}

P: Panel Veri, TS: Zaman Serisi, CS: Yatay kesit.

\section{MODEL: VERI SETİ VE DEĞİŞKENLERIN TANIMI}

Çalışmada kullanılan veri seti, 33 OECD ülkesinin modelde ihtiyaç duyulan verilerinden oluşmaktadır. Esas itibariyle çalışmada OECD ülkelerinin seçilmesinin altında yatan neden askeri harcama verilerinin bu ülkelerce göreli olarak sağlıklı bildirilmesinden kaynaklanmaktadır. Bununla birlikte İzlanda kayda değer savunma harcaması yapmayan 
izole bir ülke konumunda olduğundan analizden dışlanmıştır.

Tablo 3: Analize Konu Olan OECD Ülkeleri

\begin{tabular}{cccccc}
\hline Sayı & Ülke & Sayı & Ülke & Sayı & Ülke \\
\hline 1 & Avustralya & 12 & Yunanistan & 23 & Polonya \\
2 & Avusturya & 13 & Macaristan & 24 & Portekiz \\
3 & Belçika & 14 & İlanda & 25 & Slovakya \\
4 & Kanada & 15 & İsrail & 26 & Slovenya \\
5 & Şili & 16 & İtalya & 27 & Güney Kore \\
6 & Çekya & 17 & Japonya & 28 & İspanya \\
7 & Danimarka & 18 & Lüksemburg & 29 & İsveç \\
8 & Estonya & 19 & Meksika & 30 & İsviçre \\
9 & Finlandiya & 20 & Hollanda & 31 & Türkiye \\
10 & Fransa & 21 & Yeni Zelanda & 32 & Birleșik Krallı \\
11 & Almanya & 22 & Norveç & 33 & ABD \\
\hline
\end{tabular}

Veri dönemi 1996-2016 dönemini kapsamaktadır. Veri dönem aralığının 19962016 arası seçilmesinin nedeni otuz üç ülkenin sağlıklı veri bildirimi açısından geriye gidilebilecek sınırın 1996 olmakla birlikte, askeri harcamaların siyasi doğası nedeniyle çok yeni verilerin iptal edilen siparişler dolayısıyla gerçeği yansıtmayıșıdır. Askeri harcama büyüklükleri milyar dolar cinsinden tanımlanmıştır. Askeri harcamalar (M) ve askeri harcamaların GSYIH'ye oranı (m veya $M / Y$ ) verileri Stockholm International Peace Research Institute (SIPRI) veri tabanlarından alınmıştır. Diğer değişkenlere gelinecek olursa, ülkelerin GSYİH büyüklükleri (GSYİH/GDP), 15 yaş ve üzeri çalışabilir nüfusun büyüklüğü (L), tasarruf oranlarını temsilen kullanılan yatırımların GSYİH'ye oranı (S) ve askeri olmayan kamu harcamaları değişkenleri $(\mathrm{N})$ ise OECD ve Dünya Bankası veri tabanlarından elde edilmiştir. Sonuç olarak, 33 ülkeye ait 726 gözlemden ve dengeli panelden oluşan veri seti; bu çalışmaya konu olan örneklem büyüklügünü oluşturmaktadır. Çalışmanın ampirik bulgularının elde edilmesinde Stata-14 paket programından yararlanılmış olmakla birlikte analize konu olan ülkeler İzlanda haricinde tüm
OECD ülkelerini içermekle birlikte bu ülkelerin listesi Tablo 3'te verilmiştir.

Çalışmada Tablo 4'te verilen Feder-Ram modeline ait temel tanımlayıcı istatistikleri ele almadan önce bu modele dâhil edilen askeri olmayan kamu harcamaları parametresini denkleme eklendiğinde model aşağıdaki gibi tanımlanabilir:

$\widehat{Y}=\beta_{1} \widehat{L}+\beta_{2} \frac{I}{Y}+\beta_{3} \frac{M}{Y} \widehat{M}+\beta_{4} \widehat{M}+\beta_{5} \frac{N}{Y} \widehat{N}+\epsilon$

Ekonometrik anlamda nihai tahmin denklemimiz, hata terimi $(\varepsilon)$ kaldırılmak sureti ile aşağıdaki gibi yazılacaktır:

$\widehat{Y}=\beta_{1} \widehat{L}+\beta_{2} \frac{I}{Y}+\beta_{3} \frac{M}{Y} \widehat{M}+\beta_{4} \widehat{M}+\beta_{5} \frac{N}{Y} \widehat{N}$

Burada dikkat edilecek olursa tahmin gücümüzü güçlendirebilmek adına (19) numaralı denklemlere nazaran (20) ve (21) numaralı denklemlerde, askeri olmayan kamu harcamalarının GSYIH'ye oranı değişkeninin $\left(\frac{N}{Y} \widehat{N}\right)$ eklendiği dikkatlerden kaçmayacaktır. (21) numaralı denklemde yer alan değişkenler tanitılacak olursa:

Bağımlı değişken: $\widehat{Y}$, GSYİH büyüme oranını temsil eder.

Bağımsız değişken: $\widehat{L}$, çalışabilir işgücünün büyüme hızını ifade eder.

Bağımsız değişken: $\frac{I}{Y}$, yatırımların GSYİH'ye oranını temsil eder.

Bağımsız değişken: $\frac{M}{Y} \widehat{M}$, askeri harcamaların GSYIH'ye oranındaki değişimleri ifade eder (dışsallık değişkeni).

Bağımsız değișken: $\widehat{M}$, askeri harcamaların GSYIH'ye oranını temsil eder.

Bağımsız değişken: $\frac{N}{Y} \widehat{N}$, askeri olmayan harcamaların GSYİH'ye oranındaki değişimler.

Tablo 4: Feder-Ram Modeli Tanımlayıcı İstatistikleri

\begin{tabular}{cccccc}
\hline Değișkenler & Gözlem & Ortalama & Std.Sapma & Min. & Maks. \\
\hline$\Delta \boldsymbol{Y}$ & 693 & 0,024 & 0,029 & $-0,159$ & 0,227 \\
$\Delta \boldsymbol{L}$ & 693 & 0,010 & 0,020 & $-0,099$ & 0,104 \\
$\boldsymbol{I} \boldsymbol{Y}$ & 693 & 0,228 & 0,040 & 0,434 & 0,108 \\
$\Delta(\boldsymbol{M})$ & 693 & 325,514 & 5896,248 & $-56066,94$ & 64941,84 \\
$\Delta\left(\frac{\boldsymbol{M}}{\boldsymbol{Y}}\right)$ & 693 & 0,019 & 0,025 & 0,003 & 0,598 \\
$\Delta\left(\frac{\boldsymbol{N}}{\boldsymbol{Y}}\right)$ & 693 & 0,304 & 0,118 & 0,619 & 0,473 \\
\hline
\end{tabular}


Çalıșmada tahmin edilecek Genișletilmiș Solow modeline ait (11) numaralı ekonometrik denklemde kullanılan değişkenler ile bu değişkenlere ait temel tanımlayıcı istatistik değerleri Tablo 5'te yer almaktadır.

Bununla birlikte ekonometrik anlamda nihai tahmin denklemimiz, hata terimi $(\varepsilon)$ dışlamak sureti ile yazllacaktır.

(11) numaralı tahmin denkleminde yer alan değişkenler tanitılacak olursa, Bağımlı Değişken: $\Delta \operatorname{lny}(t)$, GSYIH büyüme oranıdır.

Bağımsız değişken: lns, yatırımların GSYï'ye oranının logaritmik değeridir. Burada tasarrufları (s) temsil eden değișken olarak yatırımların GSYIH'ye oranının logaritmik değerinin alınmasının altında yatan nedeninin yatırım-tasarruf denkliği varsayımı olduğu unutulmamalıdır.

Bağımsız değişken: $\ln (n+g+\delta)$, çalışabilir işgücünün büyüme hızı, teknolojik değişim ve aşınma payı toplamlarının logaritmik değeridir. $\ln (n+g+\delta) \quad$ değişkenine ait seri elde edilebilmesi için, iş gücünün büyüme hızının logaritmik değerlerine; $g+\delta$ toplamını temsil etmesi için 0,5 eklenmiştir.

Bağımsız değișken: $\operatorname{lnm}(t), \quad$ askeri harcamaların GSYIH'ye oranının logaritmik değeridir.

Bağımsız değişken: $\operatorname{lnm}(-1), \quad$ askeri harcamaların GSYIH'ye oranının logaritmik değerinin gecikmeli değeridir.

Tablo 5: Genișletilmiș Solow Modeli Tanımlayıcı İstatistikleri

\begin{tabular}{|c|c|c|c|c|c|c|}
\hline Değiş̧kenler & Tanım & Gözlem & Ortalama & Std.Sapma & Min. & Mak. \\
\hline $\ln Y$ & Logaritmik GSYİH & 693 & 26,842 & 1,431 & 23,127 & 30,459 \\
\hline lns & $\begin{array}{l}\text { Yatırımların } \\
\text { GSYIH'ya } \\
\text { oranının } \\
\text { Logaritması }\end{array}$ & 693 & $-1,489$ & 0,176 & $-2,224$ & $-0,833$ \\
\hline $\ln (\boldsymbol{m})$ & $\begin{array}{l}\text { Logaritmik Askeri } \\
\text { Harcamaların } \\
\text { GSYIH'ya Oranı }\end{array}$ & 693 & $-4,139$ & 0,540 & $-5,650$ & $-0,513$ \\
\hline $\ln (g+n+d)$ & $\begin{array}{l}\text { Logaritmik } \\
\text { Çalışabilir } \\
\text { işgücünün } \\
\text { büyüme hızı }\end{array}$ & 693 & 4,314 & 1,928 & $-2,995$ & 8,132 \\
\hline
\end{tabular}

\section{YÖNTEM}

Burada uygulamada başvurduğumuz yöntem çerçevesinde Sistem GMM modelinin mekanizması kısaca yer verilecektir. $\mathrm{Bu}$ bağlamda, çalışmaya aşağıdaki model temel alınmıştır.

$$
y_{i t}=\alpha y_{i, t-1}+x_{i t} \beta+\varepsilon_{i t}
$$

Burada, $y_{i t}$ ekonomik büyüme değişkenini, $x_{i t}$ ise savunma harcamaları ile beraber tanımlanan modellere özgü kontrol değişkenleri (22)'de tanımlanmaktadır. $\varepsilon_{i t}\left(\mu_{i}\right.$ ve $v_{i t}$ ) hata bileşeni ise, $\mu_{i}$ sabit etkiler ve $v_{i t}$ kendine özgü (idiosyncratic) şokların bileşimini ifade etmektedir. $i$ alt simgesi bölge (33 OECD ülkesi) ve $t$ alt simgesi ise, zaman dönemini (1996-2016) göstermektedir.

Sabit etki ve rassal etki modellerinde kullanılan gecikmeli bağımlı değiş̧kenin hata terimi ile ilgileșimli olduğu bilinmektedir. $\mathrm{Bu}$ tahmin yöntemleri ile elde edilen sonuçların tutarsız ve sapmalı olma ihtimali karşısında, gecikmeli bağımlı değișkenin yerine literatürden de bilindiği gibi araç değişkeni kullanılmaktadır. Dinamik modelde kurulan bu etkileşim açıklayıcı değişkenler ile hata terimi arasında bir içsellik sorununa da yol açmaktadır. Söz konusu içsellik ve otokorelasyon probleminin 


\section{Y. ATILLA - R. KÖK}

üstesinden gelmek amaciyla, çalışmada (Arellano ve Bond, 1991: 282-283) tarafindan geliştirilen, dinamik bir panel veri tekniği olan GMM tahmincisinden yararlanılmıștır (Anderson ve Hsiao, 1981). Birim etkileri modelden kaldırmak (gecikmeli bağımlı değişkenin hata terimi ile olan otokorelasyonu önlemek) için yukarıdaki denklemde fark alma yöntemi uygulamış, $\Delta y_{i, t-1}$ yerine $y_{i, t-2}$ 'yi araç değişken (kullanılan araç değişkenin hata terimi ile otokorelasyonsuz, açıklayıcı değişkenlerle ilgileșimli olması gerekmektedir) olarak kullanmıştır (Baltagi, 2005, : 136-138). Araç değişken kullanılarak yapılan söz konusu tahmin yöntemi, bütün moment koşullarının kullanımına imkân vermediğinden tutarlı ancak etkin değildir. (Arellano ve Bond, 1991), (Anderson ve Hsiao, 1981) çalışmalarındaki birinci fark denklemi, $\Delta y_{i, t-1}$ ve $\Delta x_{i, t-1}$ değişkenleri yerine $y$ ve $x$ 'nin bütün gecikmeli değerlerini araç değişken olarak kullanmıştır. Böylece, genelleştirilmiş momentler yöntemini (Generalized Method of Moments -GMM) geliştirmiştir. Arellano-Bover / Blundell-Bond tahmincisi ise, araç değişkelerin birinci farkını sabit etkilerden ayıran ilave varsayımlar getirerek Arellano-Bond tahmincisini genişletmiştir. $\mathrm{Bu}$ sayede, Arellano-Bond tahmincisinin tahmin sonuçlarının etkinliği, daha fazla sayıda araç değişken kullanılması nedeniyle artmış; iki eșitliğin (orijinal eşitlik ve dönüştürülmüș eşitlik) bir sistem içinde birleștirilmesine dayanan bu yaklaşım "Sistem GMM" olarak ifade edilmiştir.

Gecikmeli birinci fark değişkenlerinin $\left(y_{i t}, x_{i t}\right)$, düzey değerlerinin dönüştürülmemiş eşitlikte araç değişken olarak kullanımı Sistem GMM tahmincisinde mümkündür.

Sistem GMM tahmincisi, birinci fark eşitliğinin; araç değişken yerine geçen değişkenlerin gecikmeli düzey değerleriyle duyarlılığı arttırıp sonlu örneklem sapmasını azalttığı için fark GMM tahmincisiyle kıyaslandığında; genellikle daha etkin ve sapmasız katsayı tahmincileri elde edilmektedir. Aynı şekilde, düzey eşitliğinin ise, araç değişken yerine kullanılan değişkenlerin gecikmeli birinci fark değerleriyle bileşimine dayanan sistem GMM tahmincisi de etkin ve sapmasız katsayı tahmincileri vermektedir (Baltagi, 2005, : 147148).

İki aşamalı sistem GMM yaklaşımından elde edilen standart hatalar aşağı yönlü sapmalı olduğu için dirençli standart hataların elde edilebilmesi amaciyla Windmeijer'ın (Windmeijer, 2000) sonlu örneklem düzeltmesi tekniğinden yararlanılmıştır (Windmeijer, 2005). Ayrıca, (Windmeijer, 2005) düzeltmesi sonucu elde edilen standart hatalar sonucunda varyans-kovaryans tahminleri de değișen varyansa karşı dirençli hale gelmektedir.

Literatürde iki aşamalı sistem GMM ve fark GMM yaklaşımları yaygın olarak kullanılmakla birlikte burada, rassal yürüyüşe yakın değişkenlerle çalışıldığında daha güvenilir sonuçlar veren iki aşamalı sistem GMM tercih edilmiştir (Roodman, 2009: 99-100). Sistem GMM tahmincisi fark denkleminin yanı sıra düzey denklemini de dikkate alarak bunları bir "sistem" bünyesinde birleştirmektedir.

Sistem GMM tahmincisinin güvenilirliği için üç temel koşul bulunmaktadır (Roodman, 2006: 33-42): (i) GMM tahmincisi hata teriminin ikinci dereceden otokorelasyonun yokluğu koşulunu sağlamalıdır. Boş hipotezler birinci dereceden / ikinci dereceden otokorelasyonun olmadığı şeklinde tanımlandığı için AR(1)'de boş hipotezin reddedilmesi ya da kabul edilmesi, AR(2)'de ise boş hipotezin mutlaka kabul edilmesi koşulu uygun tanı istatistiklerinin geçerliliğine bağlıdır. (ii) Sistem GMM, sapmalı tahminlere yol açabilecek çok sayıda "zayıf" araç değişken ortaya çıkardığından, araç değişken sayısının gözlem sayısını aşmaması gerekmektedir. Ayrıca Hansen test istatistiğine ait olasılık değerinin 0,05 veya 0,10 düzeyinden büyük olması (araç değişkenlerin uygunluğunu gösteren aşırı tanımlama kısıtlarının geçerliliği yönünde boş hipotezin kabulü anlamına gelmekte) araç değişkenlerin geçerli olduğu, diğer bir deyişle modelin doğru tanımlandığını ifade etmektedir. Geçerli moment koşulları altında Hansen test istatistiği asimptotik olarak ki-kare dağllımına 
yaklaşmaktadır. (iii) Modelde Sistem GMM'in geçerliliği için yakınsama göstergesi olarak kabul edilen bağımlı değişkenin gecikmeli değerinin birden küçük olması bir gerekliliktir (Roodman, 2006). Sistem GMM yöntemiyle ilgili yukarıda yapılan kısa tanıtımın ardından çalıșmanın analitik bulguları önce Feder-Ram modelinden başlamak suretiyle irdelenebilir.

\section{ANALIZ}

Așağıdaki Tablo 6'da Feder-Ram Modeli GMM tahmin sonuçları yer almaktadır.

Tablo 6: Feder-Ram Modeli GMM Tahmin Sonuçları (Konsolide)

\begin{tabular}{|c|c|c|c|}
\hline \multicolumn{4}{|c|}{ Bağımlı Değișken: $\Delta Y$} \\
\hline Değişkenler & Model I & Model II & Model III \\
\hline$\Delta Y(-1)$ & $\begin{array}{c}0,336^{* * *} \\
(8,12)\end{array}$ & $\begin{array}{c}0,189 * * * \\
(3,07)\end{array}$ & $\begin{array}{c}0,307^{* * *} \\
(7,64)\end{array}$ \\
\hline$\Delta L$ & $\begin{array}{c}0,356^{* * *} \\
(17,62)\end{array}$ & $\begin{array}{c}0,242^{* * *} \\
(20,04)\end{array}$ & $\begin{array}{c}0,169^{* * *} \\
(4,95)\end{array}$ \\
\hline$I / Y$ & $\begin{array}{l}-0,151 \\
(-0,26)\end{array}$ & $\begin{array}{c}0,519^{* * *} \\
(8,22)\end{array}$ & $\begin{array}{c}0,288^{* *} \\
(2,48)\end{array}$ \\
\hline$\Delta(\boldsymbol{M})$ & $\begin{array}{c}0,106 * * * \\
(4,65)\end{array}$ & $\begin{array}{c}0,600^{* * *} \\
(54,39)\end{array}$ & $\begin{array}{c}0,516^{* * *} \\
(17,18)\end{array}$ \\
\hline$\Delta\left(\frac{\boldsymbol{M}}{\boldsymbol{Y}}\right)$ & & $\begin{array}{c}-0,557^{* * *} \\
(-40,14)\end{array}$ & $\begin{array}{c}-0,352^{* * *} \\
(-13,87)\end{array}$ \\
\hline$\Delta\left(\frac{N}{Y}\right)$ & & & $\begin{array}{l}0,021^{*} \\
(1,85)\end{array}$ \\
\hline C & $\begin{array}{c}13,069^{* * *} \\
(8,22)\end{array}$ & $\begin{array}{c}14,094^{* * *} \\
(14,98)\end{array}$ & $\begin{array}{l}9,89 * * * \\
(12,44)\end{array}$ \\
\hline Wald- $\chi^{2}$ (chi2) (olasılık) & 0,000 & 0,000 & 0,000 \\
\hline $\mathbf{N}$ & 693 & 693 & 693 \\
\hline AR1 (olasılık) & 0,043 & 0,036 & 0,045 \\
\hline AR2(olasilık) & 0,245 & 0,214 & 0,314 \\
\hline Hansen (olasılık) & 0,620 & 0,776 & 0,324 \\
\hline
\end{tabular}

Not $1: * * *, * *$, sirasıyla $\% 1, \% 5$ ve $\% 10$ önem düzeyinde anlamlılığı ifade etmektedir.

Not 2: Parantez içindeki değerler Windmeijer (2005) sonlu örneklem düzeltmesi ile tahmin edilen dirençli (robust) standart ha talara ait t-istatistiği değerleridir. AR(1) ve AR(2) birinci ve ikinci dereceden otokorelasyonun olasılık değerleridir. Hansen testi araç değişkenlerin geçerliliğini öne süren boş hipoteze ait olasılıkları göstermektedir. Wald testi olasılık değerleri modelin anlamlılığını vermektedir.

Modelde dinamik özelliklerin geçerliliğine yönelik bilgi veren gecikmeli bağımlı değişkene $\Delta Y(-1)$ ait tahmin sonuçları incelendiğinde, katsayının istatistiksel olarak anlamlı ve bağımlı değişkenle pozitif korelasyonlu olduğu görülmektedir. $\mathrm{Bu}$ sonuç dinamik modelin tercih edilmesinin gerekliliği yönünde bir bulgu olarak değerlendirilebilir.

Tablo 6'da yer alan GMM sonuçları incelendiğinde modelde birinci dereceden otokorelasyonun (AR(1)) olmadığını öne süren boş hipotez reddedilirken; ikinci dereceden otokorelasyonun $(\mathrm{AR}(2))$ olmadığı yönündeki boş hipotez kabul edilmektedir. Hansen'in (1982) aşırı-belirleme test sonuçları incelendiğinde; boş hipotezin kabul edilmesi araç değişkenlerin geçerli olduğunu göstermektedir.

Wald testine ait olasılık değerleri (sıfir hipotezinin reddedilmesi) ise modelin genel olarak anlamlı olduğu yönünde bilgi vermektedir. Sonuçlar birlikte değerlendirildiğinde; çalışmada kullanılan GMM yönteminin geçerliliğine yönelik gerekli koşulların yerine getirildiğini söylemek mümkündür.

Yukarıda yer alan modelin her üç sürümünün tahmin sonuçlarını içeren tablomuz incelendiğinde şu yorum önem kazanmaktadır:

Model 1'de tahmin edilen katsayı sonuçlarına göre bir dönem gecikmeli büyüme oranı değişkeninin katsayısının pozitif ve istatistiksel olarak anlamlı olduğu bulgusu elde edilmiştir. 


\section{Y. ATILLA - R. KÖK}

Dolayısıyla ilgili ülkelerin büyüme oranı değişkenleri kalıcılı göstermektedir. İşgücünün büyüme hızını gösteren katsayı pozitif ve istatistiksel olarak anlamlıdır. $\mathrm{Bu}$ sonuç aynı zamanda kuramsal beklentilerle de uyumludur (Mankiw, Romer, ve Weil, 1992). Buna göre işgücünün büyüme hızındaki \%1'lik değişme GSYIH'nin büyüme hızı üzerinde \% 0,356'lık bir artışa neden olmaktadır. Öte yandan savunma harcamalarındaki artış oranının GSYİH'nin büyüme oranı üzerindeki etkisi ise \%0,106 olup istatistiksel olarak anlamlıdır.

Model 2 savunma harcamalarındaki değişimin GSYİH'ye oranı değişkeni ile genişletilmiştir. Model 2'de dinamik katsayı pozitif ve anlamdır. Bir dönem önceki GSYİH büyüme oranı, cari dönem büyüme oranı üzerinde pozitif etkilidir. İşgücünün büyüme hızını gösteren katsayının GSYIHH'nin büyüme oranı üzerindeki etkisinin beklentilerle uyumlu ve pozitif olduğu görülmektedir. Yatırımların GSYİH'ye oranı değişkeni, Model 1'in aksine pozitif ve istatistiksel olarak anlamlıdır. Yatırımların GSYİH'ye oranının büyüme üzerindeki pozitif etkisini yansitan bu sonuç, teorik beklentileri desteklemektedir. Çalışmanın amacı açısından, temel hipoteze esas bulgular değerlendirildiğinde askeri harcamalardaki yüzde değişmenin (esneklik) büyümeye etkisi $\% 0,60$ 'tır. Bu sonuç, Yıldırım vd. (2005) bulgusu ile uyumludur. Ancak, askeri harcamaların GSYİH'ye oranını yani büyümeye göre esnekliği $\quad(\%-0,557)$ ile Yıldırım vd. (2005) bulgusu $(\% 0,095)$ ile hem katsayının büyüklüğü hem de işareti açısından uyumsuzluk göstermektedir. Bunun nedeni, Yıldırım'ın modelinde $\Delta M$ 'nin yer almaması ile birlikte hem örnekleminin küçük olması hem de gelişmiş ülkelere göre Türkiye ve Orta Doğu ülkelerini içine alan verilerdeki olası ölçme hatalarından kaynaklanabilir. Bu bağlamda, çalışmanın özgünlügünü içeren hipotez testine dönersek yatırımların GSYIH'ye oranı katsayısı crowding in öngörüsünü doğrulamakta ve cari dönemdeki askeri harcamalardaki değişme ile uyumlu bir şekilde büyümeyi olumlu etkilemektedir. Ancak modeldeki $\Delta(M / Y)$ büyümeyi olumsuz etkilediği için $(-\% 0,557)$ temel hipotezdeki öngörünün reddi sonucunu doğurmaktadır. Bunun anlamı, zamana bağlı olarak değişme hızının olumsuz olduğunu gösterir. Ayrıca, Model 3 dikkate alındığında, bu sonuçlar I/Y açısında \%0,288'e, $\Delta M$ açısında $\% 0,516$ ya düşmekte; $\Delta(M / Y)$ açısından ise $\% 0,352$ şeklinde negatif etki azalmaktadır. Ayrıca, modele askeri olmayan kamu harcamalarının GSYIH'ye oranının dâhil edildiği genişletilmiş modelin katsayısı istatistiksel olarak anlamlıdır. Buna göre askeri harcamalardaki yüzde değişmenin büyüme üzerinde negatif etki yaratmış olması temel hipotezimizi reddi sonucunu doğurmaktadır. Yine, bu sonuç literatür bulgusu olarak Yıldırım vd. (2005) ile karşılaştırdığımızda aynı tahminciler $\% 0,59$ ve $\% 0,095$ ve katsayı işaretleri pozitiftir. bu bulgu, crowding-in beklentisini doğrularken askeri harcamalardaki değişme de \%0,0607'lık bir pozitif etki yaratmaktadır. Ancak, askeri olmayan kamu harcamaların GSYİH'ye oranındaki değişim katsayısı \%0,021 olup I/Y ile karşılaştırıldı̆̆ında yine katsayı pozitif olmakla birlikte yatırımlara göre değişim hızı crowding-out etkisi yaratmaktadır denilebilir. $\mathrm{Bu}$ da temel hipotezimizle uyumlu bir sonuçtur. Çalışmanın analitik bulgularına Genişletilmiş Solow Modeli ile devam edecek olursak:

Tablo 7'de yer alan GMM sonuçları incelendiğinde modelde birinci dereceden otokorelasyonun (AR(1)) olmadı̆̆ını öne süren boș hipotez reddedilirken; ikinci dereceden otokorelasyonun (AR(2)) olmadığı yönündeki boş hipotez kabul edilmektedir.

Hansen'in aşırı-belirleme test sonuçları incelendiğinde; boş hipotezin kabul edilmesi araç değişkenlerin geçerli olduğunu göstermektedir (Hansen, 1982). Wald testine ait olasılık değerleri (boş hipotezin reddedilmesi) ise Tablo 7'de yer alan modelin bir bütün olarak anlamlı olduğunu gösterir. 
Tablo 7: Genişletilmiș Solow Modeli GMM Tahmin Sonuçları

\begin{tabular}{|c|c|}
\hline \multicolumn{2}{|c|}{ Bağımlı Değişken: $\Delta \ln Y$} \\
\hline $\ln [Y(-1)]$ & $\begin{array}{c}-0,017^{* * *} \\
(-4,72)\end{array}$ \\
\hline $\operatorname{lns}$ & $\begin{array}{c}0,015^{* * *} \\
(3,71)\end{array}$ \\
\hline $\ln (g+n+\delta)$ & $\begin{array}{c}0,007^{* * *} \\
(5,49)\end{array}$ \\
\hline $\ln (m)$ & $\begin{array}{c}-0,069^{* * *} \\
(-28,45)\end{array}$ \\
\hline $\ln [m(-1)]$ & $\begin{array}{c}0,077^{* * *} \\
(31,79)\end{array}$ \\
\hline C & $\begin{array}{c}0,537 * * * \\
(5,57)\end{array}$ \\
\hline Wald- $\chi^{2}$ (chi2) (olasılık) & 0,000 \\
\hline $\mathbf{N}$ & 693 \\
\hline AR1 (olasılık) & 0,006 \\
\hline AR2(olasılık) & 0,156 \\
\hline Hansen (olasılık) & 0,972 \\
\hline
\end{tabular}

Tablo 7'de Genişletilmiş Solow Modeline ait sistem GMM tahmin sonuçları değerlendirildiğinde büyüme oranının gösteren GSYiH değișkeninin bir dönem önceki değerinin $[\operatorname{lnY}(-1)]$ cari dönem büyüme üzerindeki etkisinin negatif ve istatistiksel olarak anlamlı olması kalıcılığı ifade eden katsayının etkisinin, yani esnekliğinin negatif olması anlamına gelir. Dolayısıyla bir önceki dönem gelirdeki \%1 lik bir değişmenin $\% 0,017$ bir değişmeye karşıllı geldiği görülmektedir. Bu durum, Genişletilmiş Solow Modeli 'nin sistem GMM metoduyla çözümlenmesinin sonuçlarının ihtiyatla yorumlanması gerekliliğini ortaya koyar. Nitekim Genişletilmiş Solow Modeli statik bir model kurgusu içerdiği için lny(-1)'in negatif olması GMM metodu açısından zayıf bir bulgudur. Bu sonucun Hou ve Chen (2012) bulgusuyla uyumlu olması kanaatimizi güçlendirmektedir. Modelde yer alan tasarruf değişkeninin (tasarrufların yatırımlara eşit olduğu varsayımı altında) esneklik katsayısı $\% 0,015$ olup büyüme üzerindeki etkisi pozitiftir. Burada, tasarrufların yatırımlara eşitliği varsayımı model açısından zayıf bir olgu olarak değerlendirilebilir. $\ln (n+g+\delta)$ : Çalışabilir işgücünün büyüme hızı, teknolojik değişim ve aşınma payı toplamlarının logaritmik değeri olan bağımsız değişken tahmincisinin büyüme üzerindeki etkisi olumlu olup katsayısı \%0,007'dir ve zayıf bir etki yaptığı şeklinde yorumlanabilir. lnm: Logaritmik askeri harcamaların GSYIH'ye oranı değişkeninin katsayısı anlamlıdır ve - $\% 0,069$ etkiye sahiptir. Bu katsayının işaretinin negatif olması temel hipotezin reddini doğuran bir sonuç olarak değerlendirilebilir ve Feder-Ram sonuçlarıyla uyumlu olup temel hipotezin reddedilmesi sonucunu doğurur. $\operatorname{lnm}(-1)$ katsayısının büyüme üzerindeki etkisi ise $\% 0,77^{\prime}$ lik katsayı ile pozitif etki yaratmaktadır. $\mathrm{Bu}$ durum, modelde yer alan dinamik araçsal değişken olarak askeri harcamaların uzun dönem etkisine karşıllı gelmektedir ve tasarruf/yatırım benzeri crowding-in etkisi yaratmaktadır. Özetle Genişletilmiş Solow Modeli bulguları Feder-Ram modeli bulgularıyla karşılaştırıldığında, Feder-Ram modelinin tahmincileri üzerinden politika önermesi geliştirmenin daha etkin bir yaklaşımın olacağının delili sayılabilir.

\section{SONUÇ}

Metin içinde belirtildiği gibi üretim ve ekonomik büyümenin temel unsurlarının 


\section{Y. ATILLA - R. KÖK}

emek, sermaye birikimi, teknoloji ve beșeri sermaye odaklı olduğu bilinmektedir. Bununla birlikte, büyümenin ana dinamiği niteliğindeki iki olgudan biri olan sermaye birikimi, uzun dönemli ekonomik büyüme için gerekli ancak yeterli koşul değildir. Uzun dönemli ekonomik büyümenin itici gücü daha ziyade teknolojidir. Teknolojik ilerleme, sermayenin verimliğini/etkinliğini arttırırken; etkin nüfus büyümesinin kaynaklar üzerinde ortaya koyduğu olumsuz etkiyi telafi eden yegâne faktör olarak, sürekli büyümenin ana kaynağıdır. Çalışma konusuyla ilgili literatürden bilinen çalışmalar, askeri harcamaların iktisadi büyüme ve ulusal refahı olumlu etkidiği gibi "crowding-out" yoluyla tam tersine olumsuz etki de yaratabildiğini göstermiştir. Nitekim askeri harcamaların teknoloji ve bilgi üretimi yönüyle ortaya koyduğu niteliksel yaratıcılık etkisi kaynakların etkin kullanımına olanak açarken transfer niteliğine bürünen askeri nitelikli kamu harcamalarının potansiyel olarak daha üretken alanlarda kullanılması gereken kaynakların, tüketim alanına teksifi sonucu iktisadi büyümenin uzun dönemli seyri beklenenin altında kalabilmektedir.

Feder-Ram Modeli GMM tahmin sonuçlarına göre dinamik modelin $\Delta Y(-1)$ tahmincisinin ait katsayısının anlamlı olması dinamik modelin tercih edilmesinin önemini ortaya koymaktadır. Çalışmanın analiz bulguları çerçevesinde modele konu olan panel yapı içinde büyüme oranının gecikmeli değerini, uzun dönem kalıcılık göstergesi olarak değerlendirilebiliriz. Model 2'den anlaşılacağı gibi yatırımların GSYIH'ye oranının büyüme üzerindeki pozitif etkisini yansıtan sonuç da teorik beklentileri desteklemektedir. Çalışmanın amacı açısından, temel hipoteze esas bulgular değerlendirildiğinde askeri harcamalardaki yüzde değişmenin (esneklik $\Delta M$ ) büyümeye etkisi $\% 0,60$ 'tır. Bu sonuç Yıldırım vd. (2005) bulgusu ile uyumludur.

Bu bağlamda, çalıșmanın özgünlüğünü içeren hipotez testine dönersek yatırımların GSYİH'ye oranı katsayısı crowding-in (dışlama etkisini tersine) öngörüsünü doğrulamakta ve cari dönemdeki askeri harcamalardaki değişme ile uyumlu bir şekilde büyümeyi olumlu etkilemektedir. Ancak modeldeki $\Delta(M / Y)$ büyümeyi olumsuz etkilediği için $(-\% 0,557)$ temel hipotezdeki öngörünün reddi sonucunu doğurmaktadır. Bunun anlamı, bu değişkenin değişme hızının zamana bağlı olarak büyüme üzerindeki etkisinin olumsuz olması şeklinde açıklanabilir. Model 3 dikkate alındığında, bu sonuçlar, Model 2'ye göre yatırımların GSYIH'ye payı (I/Y) açısından \%0,288'e, $\Delta M$ açısında \%0,516'ya düşmekte; $\Delta(M / Y$ ise $\% 0,352$ şeklinde negatif etkiyi azaltmaktadır. Ayrica, modele askeri olmayan kamu harcamalarının GSYIHH'ye oranı da büyümeyi olumlu etkilemektedir. Özetle, askeri harcamalardaki yüzde değişmenin büyüme üzerinde negatif etki yaratmış olması temel hipotezimizin reddi sonucunu doğurmaktadır.

Yine Tablo 7'de yer alan GMM sonuçları Genişletilmiş Solow Modeline göre incelendiğinde, büyüme oranının gösteren GSYIH değişkeninin bir dönem önceki değerinin $[\ln Y(-1)]$ cari dönem büyüme üzerindeki etkisinin negatif olması, Genişletilmiş Solow Modeli 'nin Sistem GMM metoduyla çözümlenmesinin sonuçlarının ihtiyatla yorumlanması gerekliliğini ortaya koymaktadır. Nitekim Genişletilmiş Solow Modeli statik bir model kurgusu içerdiği için lny(-1)'in negatif olması GMM metodu açısından zayıf bir bulgu sayılabilir. Bu sonucun da Hou ve Chen (2012) bulgusuyla örtüşmesi araştırma bulgularımızı güçlendirmektedir. Ayrıca Genişletilmiş Solow Modelinde yer alan tasarruf değişkeninin (tasarrufların yatırımlara eşit olduğu varsayımı altında) esneklik katsayısı \%0,015 olup büyüme üzerinde zayıf bir etkiyi gösterir. Yine, çalışabilir işgücünün büyüme hızı, teknolojik değişim ve aşınma payı toplamlarının logaritmik değeri olan bağımsız değișken tahmincisinin büyüme üzerindeki etkisi olumludur ve katsayısı \%0,007 olup, zayıf bir etki doğurmaktadır. Logaritmik askeri harcamaların GSYIH'ye oranı değişkeninin katsayısı anlamlıdır ve - $\% 0,069$ etkiye sahiptir. $\mathrm{Bu}$ katsayının işaretinin negatif olması temel 
hipotezin reddini doğuran ilave bir sonuçtur. Bununla birlikte bu bulgular, Feder-Ram sonuçlariyla uyumlu olup, temel hipotezin reddedilme gerekçesini güçlendirmektedir. $\mathrm{Bu}$ modelde, $\operatorname{lnm}(-1)$ katsayısının büyüme üzerindeki etkisinin $\% 0,77$ olduğu dikkate alınırsa, modelde yer alan dinamik araçsal değişken olarak askeri harcamaların uzun dönem etkisine karşılık gelen bir sonuç olup crowding-in (dişlama etkisinin aksine) beklentisini doğrulamaktadır. Her iki modelin analitik bulguları karşılaştırıldığında, FederRam modeli bulgularının kestirim yapma sürecinde Genişletilmiş Solow Modeli 'ne göre daha işlevsel olduğu söylenebilir ancak FederRam modelinin içerdiği teorik ve ekonometrik sorunlar vesilesiyle politika önermelerinde Genişletilmiş Solow Modelinin kullanılmasının daha uygun olacağı kanısına varılmıștır.

Çalışmanın sonuçları değerlendirildiğinde politika yapımcılarına aşağıda yer alan şu önerilerde bulunulabilir: Buna göre her iki modelde askeri harcamaların büyümeye etkisi küçük olmakla birlikte, stratejik güvenlik malı üretimi kapsamında savunma sanayi sektörünün üretim gücü önemsenmelidir. Devletlerin bekasıyla uyumlu ve zorunlu olan bir harcama kapsamindaki askeri mal ve hizmet üretiminin büyümeye katkısını teşvik edecek politikalar geliştirilmelidir. Nitekim bu makalenin yazarları araştırma bulgularıyla gözlem sonuçlarını birlikte değerlendirdiğinde, teknolojik yayılma etkisinin ancak sabit sermaye yatırımları ve ar-ge harcamalarıla ortaya çıkacağını öngörmektedirler. $\mathrm{Bu}$ bağlamda çalışmanın yazarları, özellikle nitelikli ve yüksek teknolojiye dayalı askeri harcamaların; toplam askeri harcamalar içindeki payının artırılması kanaatini politika yapımcılarına önerirler. Ayrıca, hafif silah üreten firmaların sivil talep yönünü güçlendirecek mevzuat düzenlenmesinin yapılması ile silah sanayiine destek stratejisi önemine vurgu yapan yazarlar, hem ihracat yönlü hem de sivil iç piyasa yönlü yeni düzenlemelerin iktisadi büyümeyi daha da uyaracağı beklentisini politika yapımcılarıyla paylaşmak isterler. $\mathrm{Bu}$ konuda mevcut uygulamalar kapsamındaki yasa ve yönetmeliklerin hafif silah imalatı ve tasarımlarının sivil piyasaya girmesini engellediği şeklindeki kanaatlerinin yanı sıra yaşanılan zorluklara da dikkat çekmektedir. Yazarlar araștırma sürecinde yaptığ gözlemlere atıf yaparak, atılım yapan hafif silah imalatçılarının, ihraç başarılarını dikkate almakta ve firmaların karşılaştığı zorlukların giderilmesini önermektedirler. İlgili tedbirler çerçevesinde de devlet katkısının artırılmasının ekonomiyi daha da uyaracağını öngörerek; bu alanda faaliyet gösteren küçük ve orta ölçekli firmaların serbest piyasa yapısına duyacağı güveni artıracak rekabetçi yapının teşvik edilmesinin gerekliliğine vurgu yaparlar. $\mathrm{Bu}$ konuda, yapısal politika düzenlemelerine ihtiyaç duyulduğu; tekelci yapı içinde faaliyet gösteren Makine ve Kimya Endüstrisi Kurumu'nun sivil piyasa dinamikleriyle birlikte hareket edeceği yapısal düzenlemelere kavuşturulmasının önemini belirtirler. Özellikle rekabet koșullarını doğuracak yeni düzenlemelerin iktisadi büyümeye yeni hamleler katacağını savunan yazarlara göre; kamuoyunda "insani" kaygılarla ileri sürülen hafif silahların teşvik edilmemesi konusundaki gerekçeler ihtiyatla değerlendirilmelidir. Hafif silahlara olan talebi, karşı direnç mekanizmaları üzerinden okumak yerine; ülkemiz açısından stratejik bir savunma aracı olan hafif silahların kullanımı konusunda sivil eğitim mevzuatının güçlendirilmesi ile birlikte 6136 sayılı ateşli silahlar kanununun günümüz koşullarıyla uyumlu hale getirilmesini daha önemli bir husus olarak görürler. 


\section{KAYNAKÇA}

Alexander, W. R. (1990). The Impact of Defence Spending on Economic Growth. Defence and Peace Economics, 2(1), 39-55.

Alexander, W. R. (1995). Defence Spending: Burden or Growth-Promoting? Defence and Peace Economics, 6(1), 13-25.

Anderson, T. W. ve Hsiao, C. (1981). Estimation of Dynamic Models with Error Components. Journal of the American Statistical Association, 76(375), 598-606.

Antonakis, N. (1997). Defence Spending and Growth in Greece: A Comment and Further Empirical Evidence. Applied Economics Letters, 4(10), 651-655.

Antonakis, N. (1999). Guns Versus Butter: A Multisectoral Aproach to Military Expenditure and Growth With Evidence from Greece, 19601993. Journal of Conflict Resolution, 43(4), 501520.

Arellano , M. ve Bond, S. (1991). Some Tests of Specification for Panel Data: Monte Carlo Evidence and an Application to Employment Equations. The Review of Economic Studies, 58(2), 277-297.

Ateşoğlu, H. S. ve Mueller, M. J. (1990). Defence Spending and Economic Growth. Defence and Peace Economics, 2(1), 19-27.

Atilla, Y. (2019). Doktora Tezi; Askeri Harcamaların Büyüme Üzerine Etkisi: OECD Örneği (1996-2016). İzmir: Dokuz Eylül Üniversitesi.

Baltagi, B. H. (2005). Econometric Analysis of Panel Data. Sussex: John Wiley and Sons Ltd.

Batchelor, P., Dunne, P. J. ve Saal, D. S. (2000). Military Spending and Economic Growth in South Africa. Defence and Peace Economics, 11(4), 553-571.

Benoit, E. (1978). Growth and Defence in Developing Countries. Economic Development and Culturel Change, 26(2), 271-280.
Biswas, B. (1992). Defense Spending and Economic Growth in Developing Countries. Economic Research Institute Study Papers, 92(4), Paper 18.

Biswas, B. ve Ram, R. (1986). Military Expenditures and Economic Growth in Less Developed Countries: An Augmented Model and Further Evidence. Economic Development and Culturel Change, 34(2), 361-372.

Bleaney, M. ve Nishiyama, A. (2002). Explaining Growth: A Contest Between Models. Journal of Economic Growth, 7, 43-56.

Crespo Cuaresma, J. ve Reitschuler, G. (2004). A Non-Linear Defence-Growth Nexus? Evidence From the US Economy. Defence and Peace Economics, 15(1), 71-82.

Deger, S. ve Sen, S. (1995). Military Expenditures and Developing Countries. K. Hartley, ve T. Sandler içinde, Handbook of Defence Economics, 1, Amsterdam Elsevier, 275-307.

Dunne, J. P. (1996). Economic Effects of Military Spending in LDC's: A Survey. The Peace Devidend. North Holland: N.P. Gleditsch, A. Cappelen, O. Bjerkhold, R. Smith and P. Dunne, 64, 439.

Dunne, J. P., Smith, R. P. ve Willenbocker, D. (2005). Models of Millitary Expenditure and Growth: A Critical Review. Defence and Peace Economics, 16(6), 449-461.

Dunne, P., Nikolaidou, E. ve Smith, R. (2002). Military Spending, Investment and Economic Growth in Small Industrialising Economies. The South African Journal of Economics, 70(5), 789790.

Dunne, J. P. ve Nikolaidou, E. (2012). Defence Spending And Economic Growth In The EU15. Defence and Peace Economics, 23(6), 537-548.

Dunne, J. P. (2012). Military Spending, Growth, Development and Conflict. Defence and Peace Economics, 23(6), 549-557. 
Feder,G. (1983). On Exports on Economic Growth. Journal of Development Economics, 12(1-2), 59-73.

Hansen, L. P. (1982). Large Sample Properties of Generalized Method of Moments Estimators. Econometrica, 50(4), 1029-1054.

Heo, U. (1996). The Political Economy of Defence Spending in South Korea. Journal of Peace Research, 33(4), 483-490.

Heo, U. (2000). The Defence-Growth Nexus in The United States Revisited. American Politics Quarterly, 28(1), 110-127.

Heo, U. (2009). The Relationship Between Defense Spending and Economic Growth in the United States. Political Research Quarterly, 63(4), 760-770

Heo, U. ve DeRouen Jr., K. (1998). Military Expenditures, Technological Change, and Economic Growth in the East Asian NIC's. The Journal of Politics, 60(3), 830-846.

Heo, U. ve Hahm, S. D. (2006). Politics, Economics and Defense Spending in South Korea. Armed Forces and Society, 32(4), 604622.

Heo, U. ve Kwang , H. R. (1998). Military Expenditures and Economic Growth in South Korea and Taiwan. International Interactions, 24(2), 171-186.

Hou, N. ve Chen, B. (2012). Military Expenditure and Economic Growth In Developing Countries: Evidence from System GMM Estimates. Defence and Peace Economics, 24(3), 183-193.

Huang, C. ve Mintz, A. (1990). Ridge Regression Analysis of the Defence-Growth Trade off in The United States. Defence and Peace Economics, 2(1), 29-37.

Keller, K., Poutvaara, P. ve Wagener, A. (2009). Military Draft and Economic Growth in OECD Countries. Defence and Peace Economics, 20(5), 373-393.

Klein, T. (2004). Military Expenditure and Economic Growth: Peru 1970-1996. Defence and Peace Economics, 15(3), 275-288.
Knight, M., Loayza, N. ve Villanueva, D. (1996, February). The Peace Dividend: Military Spending Cuts and Economic Growth. The World Bank Policy Research Department Macro Economics and Growth Division and International Monetary Fund, 43(1). 1-37.

Lee, K., Pesaran, M. H. ve Smith, R. (1997). Growth and Convegence in a Multi-Country Empirical Stochastic Solow Model. Journal of Applied Econometrics, 12(4), 357-392.

Linden, M. (1992). Military Expenditure, Goverment Size and Economic Growth in The Middle East in The 1973-85. Journal of Peace Research, 29(3), 265-270.

Mankiw, N. G., Romer, D. ve Weil , D. N. (1992). A Contribution to the Empirics of Economic Growth. The Quarterly Journal of Economics, 107(2), 407-437.

Mintz, A. ve Huang, C. (1990). Defence Expenditures, Economic Growth and the "Peace Dividend". The American Political Science Review, 84(4), 1283-1293.

Mintz, A. ve Stevenson, R. T. (1995). Defence Expenditures, Economic Growth and the 'Peace Dividend' A Longitudinal Analyses of 103 Countries. Journal of Conflict Resolution 39(2), 283-305.

Murdoch, J. C., Pi, C.-R. ve Sandler, T. (1997). The Impact of Defense and Non-Defense Public Spending on Growth in Asia and Latin America. Defence and Peace Economics, 8(2), 205-224.

Reitschuler, G. ve Loening, J. L. (2005). Modeling the Defense-Growth Nexus in Guatemala. World Development, 33(3), 513526.

Roodman, D. (2006). How to Do xtabond2. North American Stata Users Group Meetings , 130. Center for Global Development.

Roodman, D. (2009). How to Do Xtabond2: An Introduction To Difference and System GMM in Stata. The Stata Journal, 9(1), 86-136.

Sala-i-Martin, X., Doppelhofer, G. ve Miller, R. I. (2004). Determinats of Long-Term Growth: A Bayesian Averaging of Classical Estimates 


\section{Y. ATILLLA - R. KÖK}

(BACE) Aproach. National Breau of Economic Research, 94(4), 813-835

Sezgin, S. (1997). Country Survey X: Defence spending in Turkey. Defence and Peace Economics, 8(4), 381-409.

Sezgin, S. (2000). A Note on Defence Spending in Turkey: New Findings. Defence and Peace Economics, 11(2), 427-435.

Smith, A. (1776). Wealth of The Nations.

Smith, R. P. (2000). Defence Expenditure and Economic Growth: In Making Peace Pay. N. P. Gleditsch, G. Lindgren, N. Mouhleb, S. Smith, ve I. de Soysa içinde, $A$ Bibliography on Disarmament and Conversion, Laremont: Regina Books, 15-24.

Smith, R. P. ve Dunne, P. (2001). Military Expenditure Growth and Investment. Birkbeck College Working Paper, 1-19.

Stewart, D. B. (1991). Economic Growth and the Defense Burden in Africa and Latin America: Simulations From a Dynamic Model. Economic Development and Cultural Change, 40(1), 189207.

Stroub, M. D. ve Hackelman, J. C. (2001). Size of the Military Sector and Economic Growth: A Panel Data Analysis of Africa and Latin America. Journal of Applied Economics, 4(2), 329-360.
Ward, M. D., Davis, D. R. ve Chan, S. (1993). Military Spending and Economic Growth in Taiwan, Armed Forces and Society, 19(4), 533550.

Windmeijer, F. (2000). A Finite Sample Correction For The Variance of Linear Two Step GMM Estimators. Institute of Fiscal Policies Working Paper, 1-19.

Windmeijer, F. (2005). GMM for Panel Count Data Models. Centre for Microdata Methods and Practice (cemmap) Working Paper, 1-28.

Yeşilyurt, M. E. ve Elhorst, J. P. (2017). Impacts of Neighboring Countries on Military Expenditures: A Dynamic Spatial Panel Approach. Journal of Peace Research, 54(6), 777-790.

Yıldırım, J., Sezgin, S. ve Öcal, N. (2005). Military Expenditure and Economic Growth in The Middle Eastern Countries: A Dinamic Panel Data Analysis. Defence and Peace Economics, 16(4), 283-285.

Yıldırım, J. ve Öcal, N. (2014). Military Expenditures, Economic Growth and Spatial Spillovers. Defence and Peace Economics, 27(1), 1-18. 